Article

\title{
Production and Application of Biosurfactant Produced by Bacillus licheniformis Ali5 in Enhanced Oil Recovery and Motor Oil Removal from Contaminated Sand
}

\author{
Nawazish Ali ${ }^{1,2}$, Fenghuan Wang ${ }^{1,2, *} \mathbb{0}$, Baocai Xu ${ }^{1,2, *}$, Bushra Safdar ${ }^{1,2}$, Asad Ullah ${ }^{1,2,3}$, \\ Muhammad Naveed ${ }^{1,2}$, Ce Wang ${ }^{1,2}$ and Muhammad Tayyab Rashid ${ }^{4}$ \\ 1 Beijing Advanced Innovation Center for Food Nutrition and Human Health, Beijing Technology \& Business \\ University (BTBU), Beijing 100048, China; Alibtbu@gmail.com (N.A.); bushrasafdar1@gmail.com (B.S.); \\ asadbahi2016@gmail.com (A.U.); nnourang@yahoo.com (M.N.); wangce@btbu.edu.cn (C.W.) \\ 2 School of Light Industry, Beijing Technology \& Business University (BTBU), Beijing 100048, China \\ 3 Food and Marine Resources Research Center, PCSIR Laboratories Complex, \\ Shahrah-e-Dr. Salim-uz-Zaman Siddiqui, Karachi 75280, Pakistan \\ 4 School of Food and Biological Engineering, Jiangsu University, Zhenjiang 21050, China; \\ trashid208@gmail.com \\ * Correspondence: wangfenghuan@th.btbu.edu.cn (F.W.); xubaoc@btbu.edu.cn (B.X.); \\ Tel.: +86-10-68985252 (F.W.); +86-10-68985332 (B.X.)
}

Received: 18 November 2019; Accepted: 2 December 2019; Published: 4 December 2019

\begin{abstract}
The present study describes the production of biosurfactant from isolate B. licheniformis Ali5. Seven different, previously-reported minimal media were screened for biosurfactant production, and two selected media were further optimized for carbon source. Further, various fermentation conditions such as $\left(\mathrm{pH} 2-12\right.$, temperature $20-50{ }^{\circ} \mathrm{C}$, agitation speed $100-300 \mathrm{rpm}, \mathrm{NaCl}\left(0-30 \mathrm{~g} \cdot \mathrm{L}^{-1}\right)$ were investigated. The partially purified biosurfactant was characterized by Fourier transform infrared spectroscopy (FTIR) and matrix-assisted laser desorption/ionization time-of-flight mass spectroscopy (MALDI-TOF MS) and found a lipopeptide mixture, similar to lichenysin-A. Biosurfactant reduced surface tension from 72.0 to $26.21 \pm 0.3$ and interfacial tension by $0.26 \pm 0.1 \mathrm{mN} \cdot \mathrm{m}^{-1}$ respectively, biosurfactant yield under optimized conditions was $1 \mathrm{~g} \cdot \mathrm{L}^{-1}$, with critical micelle concentration (CMC) of $21 \mathrm{mg} \cdot \mathrm{L}^{-1}$ with high emulsification activity of (E24) $66.4 \pm 1.4 \%$ against crude oil. Biosurfactant was found to be stable over extreme conditions. It also altered the wettability of hydrophobic surface by changing the contact angle from $49.76^{\circ}$ to $16.97^{\circ}$. Biosurfactant efficiently removed (70-79\%) motor oil from sand, with an efficiency of more than 2 fold as compared without biosurfactant (36-38\%). It gave $32 \%$ additional oil recovery over residual oil saturation upon application to a sand-packed column. These results are indicative of potential application of biosurfactant in wettability alteration and ex-situ microbial enhanced oil recovery.
\end{abstract}

Keywords: lipopeptide biosurfactant; surface tension; interfacial tension; wettability alteration; sand packed column

\section{Introduction}

Crude petroleum demand increases day by day as a result of global urbanization and industrialization. Previous studies demonstrated that around $60 \%-70 \%$ of crude oil is still trapped in oil reservoirs after conventional oil-recovery methods [1]. To secure the demand, more efficient and economical oil extraction from the depleting oil resources needs some enhanced oil-recovery (EOR) technologies, which include chemical, microbial and miscible gas injections into oil wells [2-4] 
Among different EOR methods, chemical surfactants and polymers are the most utilized compounds in enhanced oil recovery. However, these chemical-enhanced oil-recovery methods are environmentally hazardous and leave undesirable residues [5]. The microbial biosurfactants are worthy alternatives to the conventional chemical EOR methods. Microbial surfactants or biosurfactants can be produced by different species of bacteria and unicellular fungi and yeast. These biosurfactants have surface active molecules which reduce the interfacial tension between an aqueous phase and hydrophobic molecules because of their amphipathic nature. In addition, biosurfactants increase bioavailability and solubilization of organic hydrophobic compounds [6]. The recent advancement in microbial-enhanced oil recovery (MEOR) technology and usage of cheaper substrate and economical bio-manufacturing applications not only improves the yield but has also improved the economical production and utilization approaches for microbial-enhanced oil recovery [7,8]. A few reports have authenticated the application and success of the ex situ enhanced oil recovery method at a laboratory scale, and reported an additional 10\%-85\% oil recovery using core floods or sand pack columns $[9,10]$. The lipopeptide surfactins and lichenysin produced by Bacillus subtilis and Bacillus licheniformis are among the most studied biosurfactants. These biosurfactants are known for lowering surface and interfacial tensions along with other properties and they are capable of mobilizing entrapped oil and hence are good candidates for MEOR application [11,12].

Biosurfactants have amphiphilic moieties produced extracellularly by a wide range of bacteria, fungi and yeast. Biosurfactants are chemicaly classified into into lipopeptides, neutral lipids, glycolipids, phospholipids, polymeric and particulate compounds [13,14]. Biosurfactants act between fluids with different polarities such as oil and water, aiding access to hydrophobic substrates by increasing the area of contact of insoluble compounds as well as improved bioavailability and mobility, leading to the biodegradation of these substrates. These properties enable biosurfactants to lower surface and interfacial tensions and also form microemulsions. These features make hydrocarbons solubilized in water [15]. Spillage of hydrocarbons is another major problem that contributes in pollution of soil and marine environments. The removal of these hydrocarbon pollutants is very difficult because of their insoluble nature. Biosurfactants again efficiently participate in biodegradation, resulting in removal of these organic and inorganic pollutants [16].

The mechanical workshops contribute thousands millions gallons of used engine oils annually and are released without any treatment, it is reported that a liter of waste engine oil can pollute one million gallon of fresh water. Hence, the remediation of waste engine oil is mandatory for environmental safety [17]. Biosurfactants' addition can improve bioremediation of pollutants with indigenous cultures due to incredible features like emulsification and de-emulsification, dispersion foaming and wetting [18]. Synthetic surfactants have been utilized for enhanced soil washing, including anionic, nonionic, cationic and mixed surfactants, some of these surfactants have proved their worth in washing capabilities for removal of organic and inorganic hydrocarbons from contaminated underground water and soils [19]. Synthetic surfactants like TritonX-100 and Tween 80 are able to enhance the concentration of non-polar compounds in the aqueous phase [20]. However, the synthetic surfactants exert toxic hazards to the environment and human health so biosurfactants are suitable alternative [9].

Thus, the aim of the present study includes: the screening and isolation of biosurfactant producing bacteria from soil, improvement of biosurfactant yield through selection of appropriate media and better carbohydrate source, characterization of the produced biosurfactant and access to its stability in harsh environmental conditions. Further, the biosurfactant's applicability was assessed for environmental applications like enhanced oil recovery in sand-packed column along with its capacity to remove hydrocarbons from contaminated sand. 


\section{Results and Discussions}

\subsection{Screening and Identification of the Bacterial Isolate}

In the present study, three morphologically distinct microbial colonies were isolated, and in particular the isolated strain named initially " $10^{-2} \mathrm{w}^{\prime}$ was recorded with the highest surface tension reduction $\left(26.37 \mathrm{mN} \cdot \mathrm{m}^{-1}\right)$, hemolytic activity (positive), oil spreading $(65 \mathrm{~mm})$, positive result in drop collapse and emulsification index $\left(\mathrm{E}_{24}\right)$ with crude oil as $66 \%$. Thus, it was selected for further studies.

The selected bacterial strain after screening parameters was identified following the technical route map: Bacterial genomic DNA extraction $\rightarrow 16 \mathrm{~S}$ rRNA bacteria conserved sequence polymerase chain reaction (PCR) amplification $\rightarrow 3730$ sequencing. Genomic DNA from selected colonies of $10^{-2} \mathrm{~W}$ and $10^{-3} \mathrm{~W}$ were extracted, universal primers 27f: AGAGTTTGATCMTGGCTCAG and 1492R: TACGGYTACCTTGTTACGACTT were used for 16S rRNA sequencing. The specific sequence obtained was compared with the database of known 16S rRNA, using BLAST (basic local alignment search tool) the strain was identified as Bacillus licheniformis and named B. licheniformis Ali5. The 16S rRNA sequence of the strain B. licheniformis Ali5 was submitted to the Gen-Bank database with accession number MN629226.

The phylogenetic tree of the strain is shown in (Figure 1).

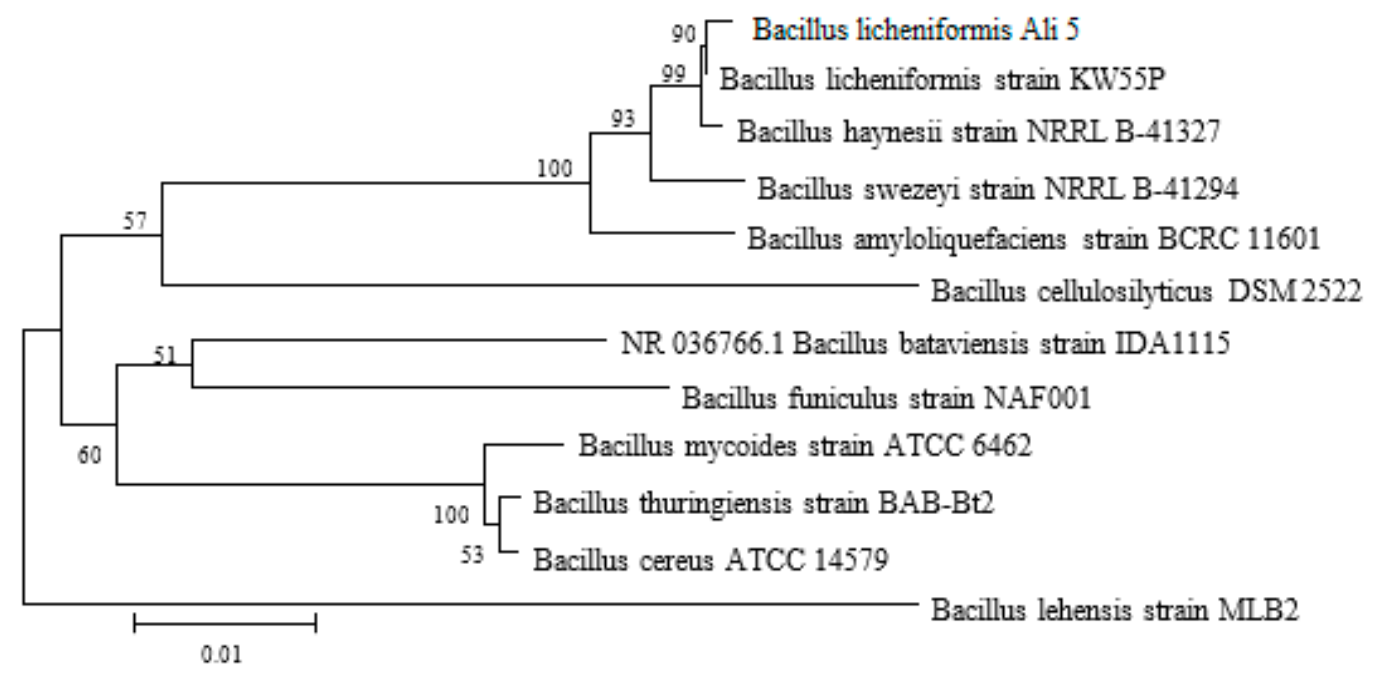

Figure 1. Phylogenetic tree of the strain through neighbor-joining methods using MEGA version 6.0. It represents how Ali5 belongs to B. licheniformis.

\subsection{Media and Carbon Source Optimization}

Microbial-enhanced oil recovery is an old technique that commenced as far back as 1926, and was formerly called "MIOR" (microbial increased oil recovery) where both microbial products and microorganisms are used for oil recovery from depleted oil wells and reservoirs. To ensure adequate energy supply in the future, MEOR is very useful [21]. Several biosurfactants reported for playing a crucial role in enhancing oil recovery by stimulating dissolution, solubilization and emulsification of hydrocarbons [22]. Lipopeptides are among several other biosurfactants that have found application in microbial enhanced oil recovery. Previously, some endospores were used for microbial enhanced oil recovery collected from soil having a hydrocarbon history. Thus, seven different minimal media were used in the present study to investigate the production of biosurfactant, $\mathrm{pH}$ variations, surface and interfacial tension and viscosity of the biosurfactant at different time intervals (24-72 h). The growth and production profile in seven minimal media are shown in Table 1 . It was observed that media M2, M6 and M7 have better growth, while very little growth was observed in media M3 and M4. The possible reason for this may be the acidic $\mathrm{pH}$ after $24 \mathrm{~h}$ of growth while the rest of the mediums have neutral to alkaline $\mathrm{pH}$. This strain showed better growth in neutral to alkaline $\mathrm{pH}$, as previously 
reported by Joshi et al. [23]. M2 and M7 both had the lowest surface tension and interfacial tension of 26.37-27.33 $\mathrm{mN} \cdot \mathrm{m}^{-1}$ and $0.78-2.60 \mathrm{mN} \cdot \mathrm{m}^{-1}$, respectively

Table 1. The growth (OD660), $\mathrm{pH}$ profile, biosurfactant production (ST = surface tension and IFT $=$ interfacial tension) and Viscosity ( $\mathrm{mPa} \cdot \mathrm{s})$ profile of $B$. licheniformis Ali5 in carbohydrate based minimal production media.

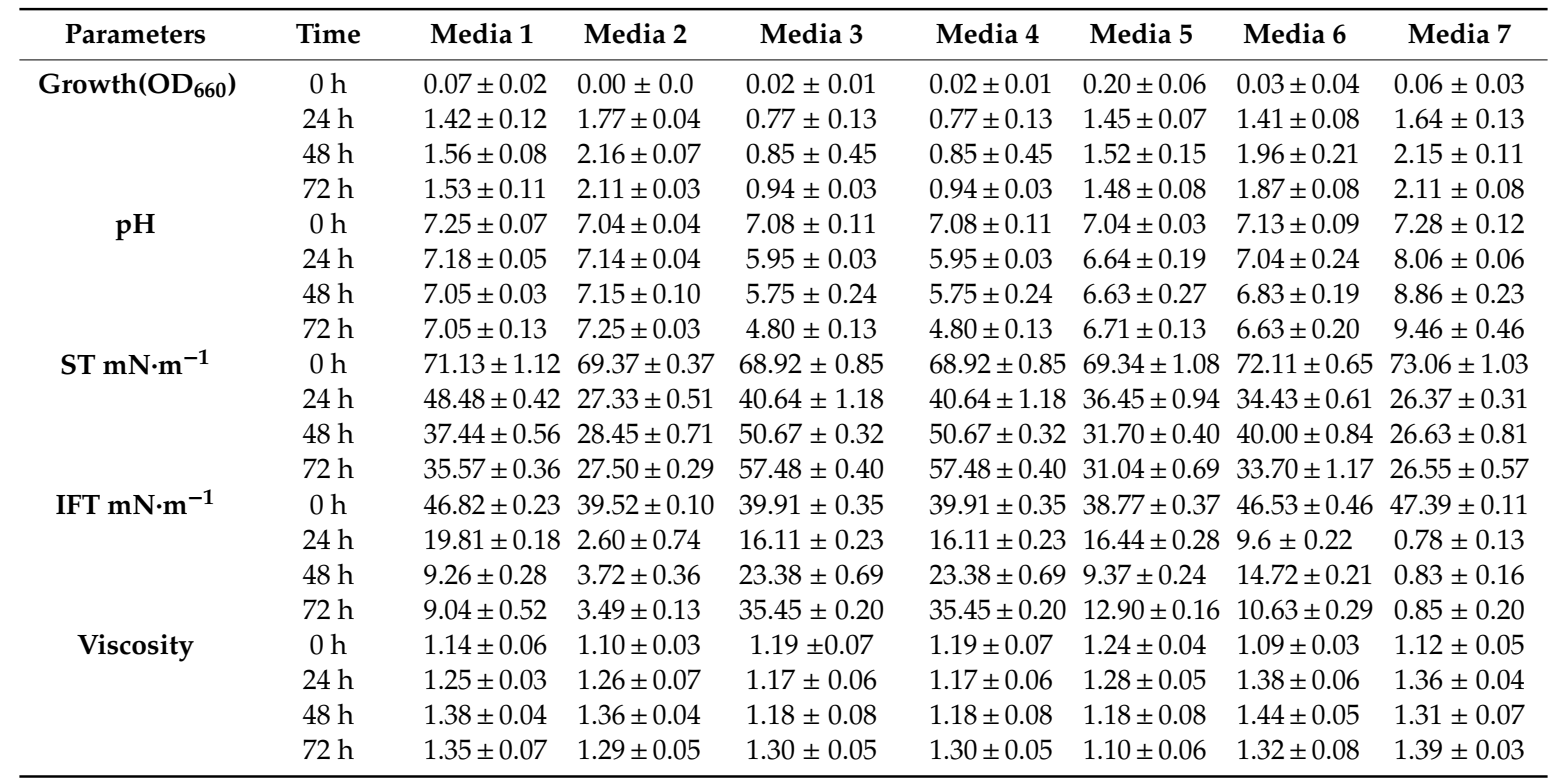

All values are means, SD $(n=3)$. ST = surface tension, IFT = interfacial tension.

Based on these results, media M2 and M7 were selected further for better carbohydrate source investigation. Both M2 and M7 media were selected for screening of carbon source (glucose, sucrose and starch). The results obtained indicating better growth, lower surface tension (ST) and interfacial tension (IFT), high emulsification index $\left(\mathrm{E}_{24}\right)$ and yield in M7 with all carbon sources. It was observed that all media containing glucose, sucrose and starch as carbon source reduced ST from 72 to $<29.6 \mathrm{mN} \cdot \mathrm{m}^{-1}$ and similar trend was observed in M7 as surface tension dropped from 73 to 26.37 and interfacial tension from 48.66 to $0.26 \mathrm{mN} \cdot \mathrm{m}^{-1}$ within $72 \mathrm{~h}$, highest emulsification $54.4 \%$ (Table 2 ). No media indicated considerable viscosity variations during $72 \mathrm{~h}$ of growth. Hence, it may be conluded that the strain B. licheniformis Ali5 did not produce biopolymer but produced only biosurfactant. The viscosity of some biopolymers was studied and found to be around 43-21,535 cP [23]. These results are in accordance with some of the previously reported bacillus species [24-26]. It is concluded from the results that the isolated strain $B$. licheniformis Ali5 gave better growth, ST, IFT, $\mathrm{E}_{24}$ and yield with glucose as carbon source. Hence, M7 with glucose as a carbon source was used for further studies. The yield of biosurfactant at different time intervals and with different hydrocarbon sources was studied and the biosurfactant was extracted by combination of acid-precipitation and methanol extraction, and then freeze-dried. The obtained yield of partially purified biosurfactant was $1.10 \pm 0.2 \mathrm{~g} \cdot \mathrm{L}^{-1}$. 
Table 2. The growth (OD660), $\mathrm{pH}$ profile, biosurfactant production (ST = surface tension and $\mathrm{IFT}=$ interfacial tension), viscosity $(\mathrm{mPa} \cdot \mathrm{s})$, emulsification index $\left(\mathrm{E}_{24}\right)$ and yield $\left(\mathrm{g} \cdot \mathrm{L}^{-1}\right)$ profile of B. licheniformis Ali5 in M2 and M7 with different carbon sources.

\begin{tabular}{|c|c|c|c|c|c|c|c|}
\hline Parameters & Time & $\begin{array}{c}\text { M2 } \\
\text { (Glucose) }\end{array}$ & $\begin{array}{c}\text { M2 } \\
\text { (Sucrose) }\end{array}$ & $\begin{array}{c}\text { M2 } \\
\text { (Starch) }\end{array}$ & $\begin{array}{c}\text { M7 } \\
\text { (Glucose) }\end{array}$ & $\begin{array}{c}\text { M7 } \\
\text { (Sucrose) }\end{array}$ & $\begin{array}{c}\text { M7 } \\
\text { (Starch) }\end{array}$ \\
\hline \multirow[t]{4}{*}{ Growth $\left(\mathrm{OD}_{660}\right)$} & $0 \mathrm{~h}$ & $00 \pm 0.00$ & $0.05 \pm 0.03$ & $0.05 \pm 0.05$ & $0.30 \pm 0.07$ & $0.03 \pm 0.02$ & $0.07 \pm 0.05$ \\
\hline & $24 \mathrm{~h}$ & $1.71 \pm 0.04$ & $1.66 \pm 0.05$ & $1.33 \pm 0.05$ & $1.64 \pm 0.05$ & $1.84 \pm 0.02$ & $1.46 \pm 0.13$ \\
\hline & $48 \mathrm{~h}$ & $2.11 \pm 0.02$ & $1.81 \pm 0.06$ & $1.51 \pm 0.04$ & $2.19 \pm 0.06$ & $2.16 \pm 0.04$ & $1.91 \pm 0.12$ \\
\hline & $72 \mathrm{~h}$ & $2.08 \pm 0.03$ & $1.74 \pm 0.02$ & $1.61 \pm 0.08$ & $2.13 \pm 0.01$ & $2.11 \pm 0.03$ & $1.73 \pm 0.05$ \\
\hline \multirow[t]{4}{*}{$\mathrm{pH}$} & $0 \mathrm{~h}$ & $7.04 \pm 0.04$ & $7.09 \pm 0.10$ & $7.06 \pm 0.07$ & $7.28 \pm 0.08$ & $7.08 \pm 0.36$ & $7.11 \pm 0.06$ \\
\hline & $24 \mathrm{~h}$ & $7.12 \pm 0.20$ & $7.22 \pm 0.06$ & $7.28 \pm 0.19$ & $7.39 \pm 0.13$ & $7.22 \pm 0.22$ & $7.50 \pm 0.24$ \\
\hline & $48 \mathrm{~h}$ & $7.15 \pm 0.17$ & $7.28 \pm 0.50$ & $7.39 \pm 0.25$ & $8.49 \pm 0.28$ & $7.37 \pm 0.04$ & $8.48 \pm 0.10$ \\
\hline & $72 \mathrm{~h}$ & $7.43 \pm 0.10$ & $7.65 \pm 0.10$ & $7.33 \pm 0.09$ & $9.01 \pm 0.12$ & $8.76 \pm 0.43$ & $8.89 \pm 0.28$ \\
\hline \multirow[t]{4}{*}{$\mathrm{ST}\left(\mathrm{mN} \cdot \mathrm{m}^{-1}\right)$} & $0 \mathrm{~h}$ & $70.26 \pm 0.29$ & $71.63 \pm 0.55$ & $72.83 \pm 0.36$ & $72.24 \pm 0.40$ & $72.87 \pm 0.48$ & $71.72 \pm 0.28$ \\
\hline & $24 \mathrm{~h}$ & $27.66 \pm 0.25$ & $27.63 \pm 0.35$ & $29.60 \pm 0.36$ & $26.21 \pm 0.33$ & $26.49 \pm 0.29$ & $26.54 \pm 0.34$ \\
\hline & $48 \mathrm{~h}$ & $28.52 \pm 0.55$ & $27.70 \pm 0.41$ & $29.22 \pm 0.29$ & $26.48 \pm 0.42$ & $27.57 \pm 0.25$ & $27.36 \pm 0.21$ \\
\hline & $72 \mathrm{~h}$ & $27.57 \pm 0.22$ & $27.57 \pm 0.14$ & $29.40 \pm 0.24$ & $26.69 \pm 0.17$ & $26.55 \pm 0.31$ & $26.53 \pm 0.14$ \\
\hline \multirow[t]{4}{*}{ IFT $\left(\mathrm{mN} \cdot \mathrm{m}^{-1}\right)$} & $0 \mathrm{~h}$ & $47.86 \pm 0.08$ & $42.51 \pm 0.09$ & $47.19 \pm 0.57$ & $48.66 \pm 0.18$ & $48.48 \pm 0.47$ & $46.82 \pm 1.39$ \\
\hline & $24 \mathrm{~h}$ & $2.47 \pm 0.18$ & $1.41 \pm 0.07$ & $2.31 \pm 0.23$ & $0.26 \pm 0.05$ & $0.77 \pm 0.02$ & $0.56 \pm 0.29$ \\
\hline & $48 \mathrm{~h}$ & $4.61 \pm 0.26$ & $2.64 \pm 0.14$ & $2.71 \pm 0.20$ & $0.35 \pm 0.07$ & $0.82 \pm 0.13$ & $0.72 \pm 0.14$ \\
\hline & $72 \mathrm{~h}$ & $3.41 \pm 0.14$ & $2.10 \pm 0.15$ & $2.53 \pm 0.29$ & $0.37 \pm 0.04$ & $0.86 \pm 0.03$ & $0.78 \pm 0.24$ \\
\hline \multirow[t]{4}{*}{ Viscosity } & $0 \mathrm{~h}$ & $1.04 \pm 0.05$ & $1.12 \pm 0.05$ & $1.17 \pm 0.09$ & $1.14 \pm 0.04$ & $1.15 \pm 0.02$ & $1.18 \pm 0.03$ \\
\hline & $24 \mathrm{~h}$ & $1.44 \pm 0.19$ & $1.59 \pm 0.09$ & $1.24 \pm 0.10$ & $1.42 \pm 0.07$ & $1.32 \pm 0.05$ & $1.43 \pm 0.07$ \\
\hline & $48 \mathrm{~h}$ & $1.43 \pm 0.09$ & $1.46 \pm 0.08$ & $1.27 \pm 0.04$ & $1.35 \pm 0.04$ & $1.31 \pm 0.04$ & $1.31 \pm 0.04$ \\
\hline & $72 \mathrm{~h}$ & $1.33 \pm 0.05$ & $1.43 \pm 0.08$ & $1.25 \pm 0.09$ & $1.39 \pm 0.06$ & $1.31 \pm 0.08$ & $1.30 \pm 0.05$ \\
\hline \multirow[t]{5}{*}{ Emulsification index $\left(E_{24}\right)$} & & Diesel & Hexadecane & Heptane & Diesel & Hexadecane & Heptane \\
\hline & $0 \mathrm{~h}$ & $19.8 \pm 2.1$ & $10.6 \pm 1.2$ & $12.7 \pm 0.8$ & $18.3 \pm 1.7$ & $12.8 \pm 1.2$ & $10.4 \pm 2.2$ \\
\hline & $24 \mathrm{~h}$ & $51.6 \pm 1.0$ & $51.6 \pm 0.6$ & $50.0 \pm 0.9$ & $53.3 \pm 0.7$ & $52.6 \pm 0.3$ & $51.8 \pm 0.6$ \\
\hline & $48 \mathrm{~h}$ & $52.8 \pm 0.7$ & $52.5 \pm 0.7$ & $51.8 \pm 1.1$ & $53.3 \pm 0.8$ & $52.8 \pm 0.2$ & $52.2 \pm 1.2$ \\
\hline & $72 \mathrm{~h}$ & $53.0 \pm 1.2$ & $52.8 \pm 0.5$ & $52.7 \pm 1.3$ & $54.4 \pm 0.9$ & $53.8 \pm 0.5$ & $52.6 \pm 0.8$ \\
\hline \multirow[t]{3}{*}{ Yield $\left(\mathrm{g} \cdot \mathrm{L}^{-1}\right)$} & $24 \mathrm{~h}$ & $0.19 \pm 0.2$ & $0.22 \pm 0.3$ & $0.18 \pm 0.3$ & $0.29 \pm 0.2$ & $0.30 \pm 0.4$ & $0.36 \pm 0.3$ \\
\hline & $48 \mathrm{~h}$ & $0.45 \pm 0.2$ & $0.43 \pm 0.2$ & $0.48 \pm 0.1$ & $0.57 \pm 0.3$ & $0.66 \pm 0.2$ & $0.39 \pm 0.2$ \\
\hline & $72 \mathrm{~h}$ & $0.21 \pm 0.1$ & $0.48 \pm 0.2$ & $0.24 \pm 0.2$ & $1.01 \pm 0.2$ & $0.98 \pm 0.1$ & $0.55 \pm 0.1$ \\
\hline
\end{tabular}

All values are means $\pm \mathrm{SD}(n=3)$. ST $=$ surface tension, $\mathrm{IFT}=$ interfacial tension.

\subsection{Effect of Environmental Conditions on Growth and Stability}

The variations in $\mathrm{NaCl}$ concentrations, $\mathrm{pH}$, temperature and agitation speed on growth were determined by measurement of surface and interfacial tension, as shown in Figure 2a-d. The effect of $\mathrm{pH}$ on ST and IFT was greatly affected by changes in $\mathrm{pH}$ below 4 while the $\mathrm{pH}$ around $4-12$ leads to only a slight change in ST and IFT. The better growth was observed towards the neutral and alkalined environment. It was also observed that the agitation speed from (100-300 rpm) and $\mathrm{NaCl}$ up to $(30 \mathrm{~g} / \mathrm{L})$ had no significant effect on surface and interfacial tension. No significant change in ST and IFT were observed at a temperature around $20-40^{\circ} \mathrm{C}$ and a slight increase in ST and IFT were seen from 40 to $50^{\circ} \mathrm{C}$.

Stability in harsh environmental conditions is considered mandatory for all chemicals to find their application in additional oil recovery (AOR). Thus, the biosurfactant was exposed to higher temperatures, $\mathrm{pH}$ and salinity as shown in Figure 3 . The studied range of temperatures were $40-110^{\circ} \mathrm{C}$, $121^{\circ} \mathrm{C}$ (15Psi for $30 \mathrm{~min}$ ) and the biosurfactant was found to be stable up to $100^{\circ} \mathrm{C}$, while a negligible change in ST and IFT was observed at $110^{\circ} \mathrm{C}$ and $121^{\circ} \mathrm{C}$. Banat et al. [27] reported that heat treatment even after autoclaving cannot change the properties of some biosurfactants. The ST and IFT values slightly change when the $\mathrm{pH}$ increased from $6-12$ but at $\mathrm{pH}$ below 4 the ST and IFT values significantly increased due to precipitation (Figure 3a). These results indicate that increased $\mathrm{pH}$ had a positive effect on surface, interfacial activity and stability of biosurfactant [28].The surface activity of the biosurfactant was accessed under different salinity concentrations and the biosurfactant performed well in a salinity test up to $30 \mathrm{~g} \cdot \mathrm{L}^{-1}$ (Figure $3 \mathrm{~b}$ ). The surface activity remained higher even at the highest salt concentration of $(30 \% w / v)$, by which it was not effected, and it exhibited high stability. Some reports have confirmed similarly good stabilities of biosurfactants produced by Bacillus and Pseudomonas aeruginosa strains $[18,29,30]$. These properties of biosurfactants make them an exceptional candidate 
for application in microbial enhanced oil recovery, since biosurfactants are excellent alternatives to chemical surfactants that are toxic, non-degradable and less activated at $4 \%-5 \%$ salinity, as discussed by Bognolo et al. [31].
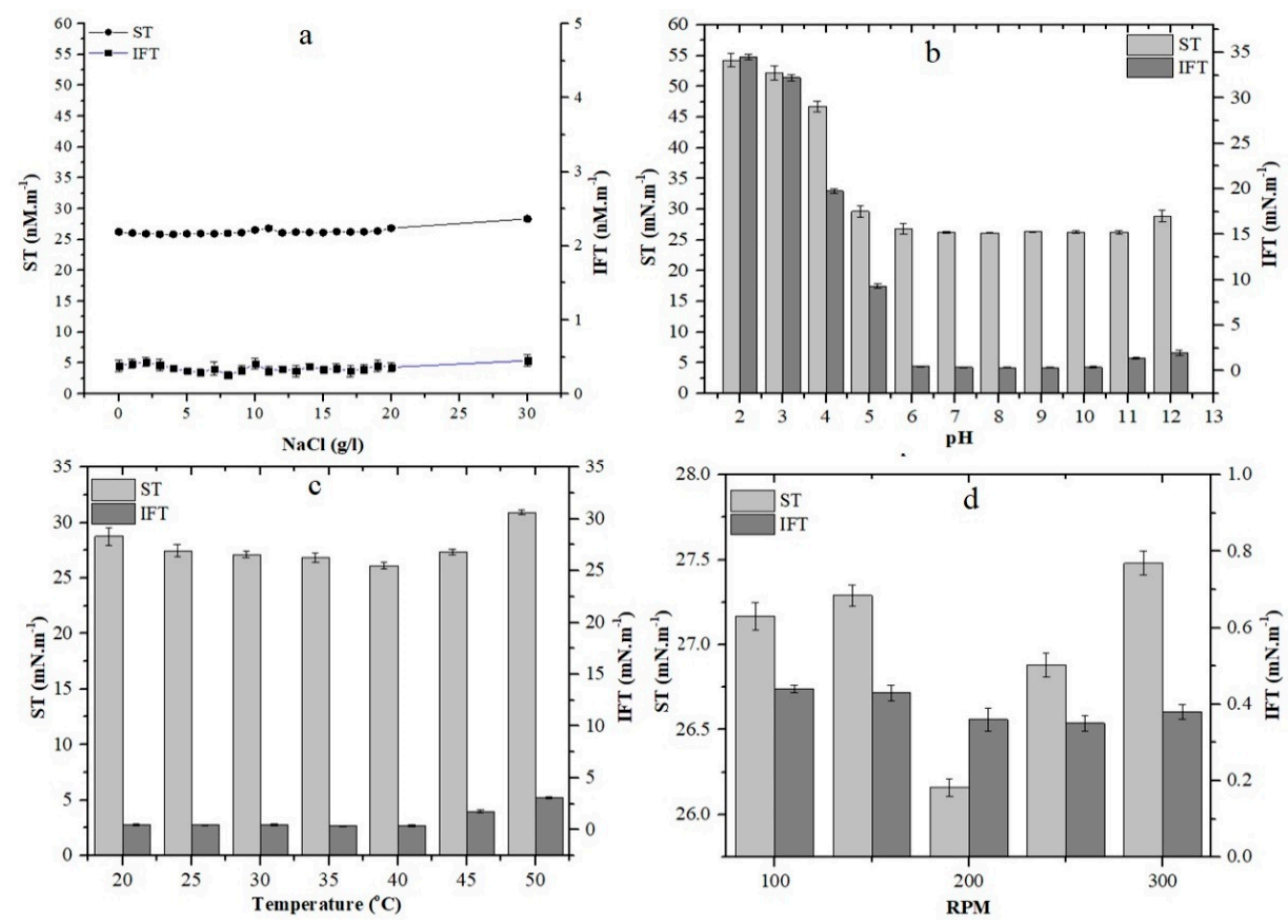

Figure 2. Effect of salinity (a) $\mathrm{pH}(\mathbf{b})$ temperature (c) agitation speed rotation per min (RPM) (d) on growth (Surface Tension and Interfacial Tension) of biosurfactant produced by B. licheniformis Ali5. The error bars represent standard deviations from three independent experiments. $\operatorname{SD}(n=3)$.
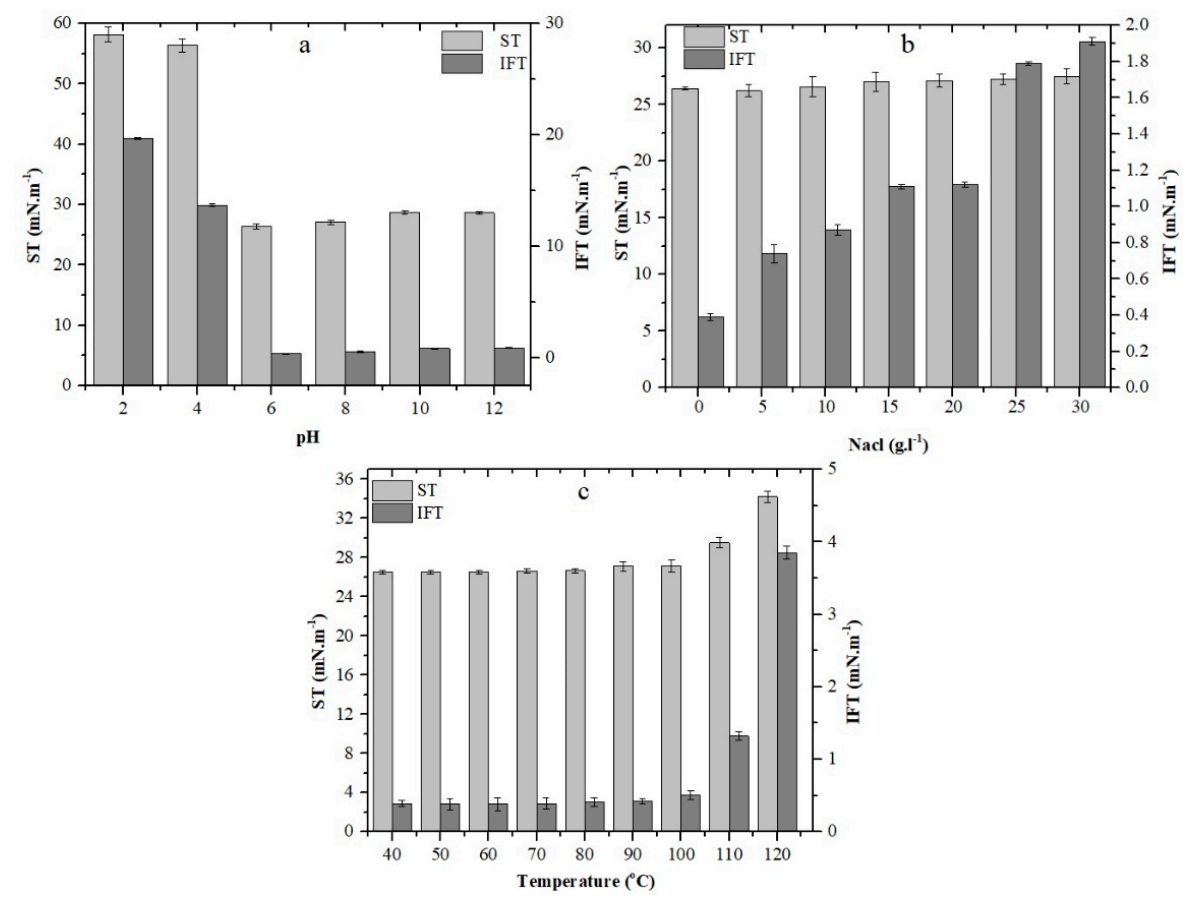

Figure 3. Effect of $\mathrm{pH}(\mathbf{a})$, salinity (b), temperature (c) on the stability (surface tension and interfacial tension) of biosurfactant produced by B. licheniformis Ali5. The error bars represent standard deviations from three independent experiments. $\mathrm{SD}(n=3)$. 


\subsection{Determination of Emulsification Index $E_{24}$}

The emulsification activity of biosurfactant containing supernatant of M7 media having glucose as a carbon source was appreciable. Emulsified hydrocarbons like kerosene, hexadecane, tridecane, tetradecane, diesel, crude oil, pristane and heptane were in the range of $50 \%-64 \%$. As shown in Table 3 the biosurfactant-produced emulsions were more stable than emulsions produced by SDS or Triton X. Biosurfactant supernatant exhibited higher $\mathrm{E}_{24}$ values of $66.4 \%, 57.6 \%$ and $56.5 \%$ against crude oil, kerosene and tetradecane, respectively. de Faria et al. [25] reported that the biosurfactant from bacillus species emulsified hydrocarbons, including hexadecane, kerosene, diesel, petrol and benzene in the range of $30 \%-80 \%$. The obtained results were similar to those obtained by Nitschke et al. [12]. A higher emulsification property (66.4\%) was observed with Xinjiang crude oil, which is an indicator of possible biosurfactant usage in enhanced oil recovery and environmental application.

Table 3. Emulsification index ( $\left.\mathrm{E}_{24}\right)$ of biosurfactant (cell-fee supernatant) produced from B. licheniformis Ali5, Triton X-100 and Sodium dodecyl sulfate against different hydrocarbons.

\begin{tabular}{cccc}
\hline Hydrocarbon & Lichenysin & Triton X-100 & SDS \\
\hline kerosene & $57.6 \pm 0.9$ & $51.8 \pm 1.4$ & $51.2 \pm 0.6$ \\
hexadecane & $53.8 \pm 0.8$ & $50.1 \pm 0.2$ & $50.6 \pm 1.4$ \\
tridecane & $55.4 \pm 1.3$ & $51.2 \pm 1.6$ & $52.3 \pm 0.5$ \\
tetradecane & $56.5 \pm 0.2$ & $48.8 \pm 0.9$ & $51.4 \pm 1.6$ \\
diesel & $54.5 \pm 1.2$ & $50.6 \pm 0.5$ & $53.8 \pm 1.9$ \\
crude oil & $66.4 \pm 1.4$ & $48.2 \pm 1.0$ & $45.2 \pm 2.2$ \\
pristane & $55.1 \pm 1.4$ & $49.8 \pm 1.2$ & $52.1 \pm 1.3$ \\
heptane & $52.4 \pm 1.0$ & $47.5 \pm 1.3$ & $52.4 \pm 1.7$
\end{tabular}

All values are means $\pm \mathrm{SD}(n=3)$. Sodium dodecyl sulfate $(0.1 \mathrm{~g} / \mathrm{L})$. Triton X: concentration of $0.1 \%(v / v)$.

\subsection{Critical Micelle Concentration (CMC) Determination}

As shown in (Figure 4b), the freeze-dried biosurfactant dissolved in Tris-HCL buffer solution $\mathrm{pH} 8$ was used to determine the CMC value and was found to be $21 \mathrm{mg} \cdot \mathrm{L}^{-1}$ with reduced surface tension to $26.42 \mathrm{mN} \cdot \mathrm{m}^{-1}$. Almost constant surface tension was observed up to $1 \mathrm{~g} \cdot \mathrm{L}^{-1}$ concentration of biosurfactant. These results are in agreement with Joshi et al. [28] and much higher than Al-Sulaimani et al. [3], and relatively lower than some other biosurfactants produced by some other Bacillus species [32-34].

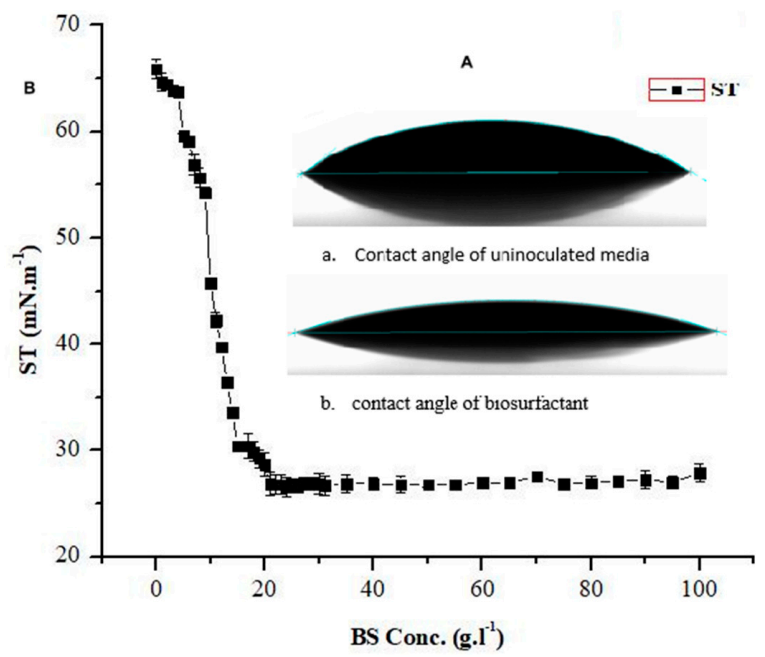

Figure 4. A (a) Contact angle of un-inoculated media $\left(49.76 \pm 1.4^{\circ}\right)(\mathbf{b})$ biosurfactant from B. licheniformis Ali5 (cell-free supernatant) (B) critical micelle concentration (CMC) of the biosurfactant produced by strain Ali5. The error bars represent standard deviations from three independent experiments. SD $(n=3)$. 


\subsection{Surface Wettability Alteration}

Surface wettability alteration has been reported as a significant mechanism for the EOR process. Wettability alteration is correlated with interfacial tension that can change water-wet to oil-wet biosurfactant surfaces, and vice versa [26]. Therefore, biosurfactant (cell-free supernatant) produced from the B. licheniformis Ali5 was studied for any effect on the hydrophobic surface of a cover slip. The results obtained for contact angle measurements are shown in (Figure $4 a, b$ ) the contact angle was reduced from $49.76 \pm 1.4^{\circ}$ of un-inoculated media to $16.97 \pm 0.84^{\circ}$ in cell-free supernatant. Joshi et al. [23] obtained results for un-inoculated media and cell-free supernatant from $55.67 \pm 1.6^{\circ}$ to $19.54 \pm 0.7^{\circ}$ respectively. Al-Wahaibi et al. [26] found the contact angle alteration from $70.6 \pm 0.3^{\circ}$ to $27.4 \pm 1.03^{\circ}$ using biosurfactant from B. subtilis B30. In the current study, the biosurfactant altered wettability to make it more water-wet and this is considered a suitable property in improving the field-scale enhanced oil recovery applications.

\subsection{Partial Structural Identification Using Fourier Transform Infrared Spectroscopy (FTIR)}

The FTIR spectrum (Figure 5) of the partially purified biosurfactant of Bacillus licheniformis Ali5 showed a similar pattern to surfactin (Sigma chemicals, USA) and peaks obtained indicate that the biosurfactant is a lipopeptide, as observed by Joshi et al. [28]. Band characteristics of the peptides were at $3323 \mathrm{~cm}^{-1}$ (NH stretching mode), and at $1629 \mathrm{~cm}^{-1}$ (stretching mode of CO-N bond); while the bands at 2957-2926, 2854, 1403, $1377 \mathrm{~cm}^{-1}$ reflected the aliphatic chains (-CH3, -CH2-) of the fractions, as described in Joshi et al. [28]. It is concluded from the results that the biosurfactant is a cyclic lipopeptide, the infrared spectrum produced is quite similar to bacilli produced Surfactin and Lichenysin as reported previously [3,23].

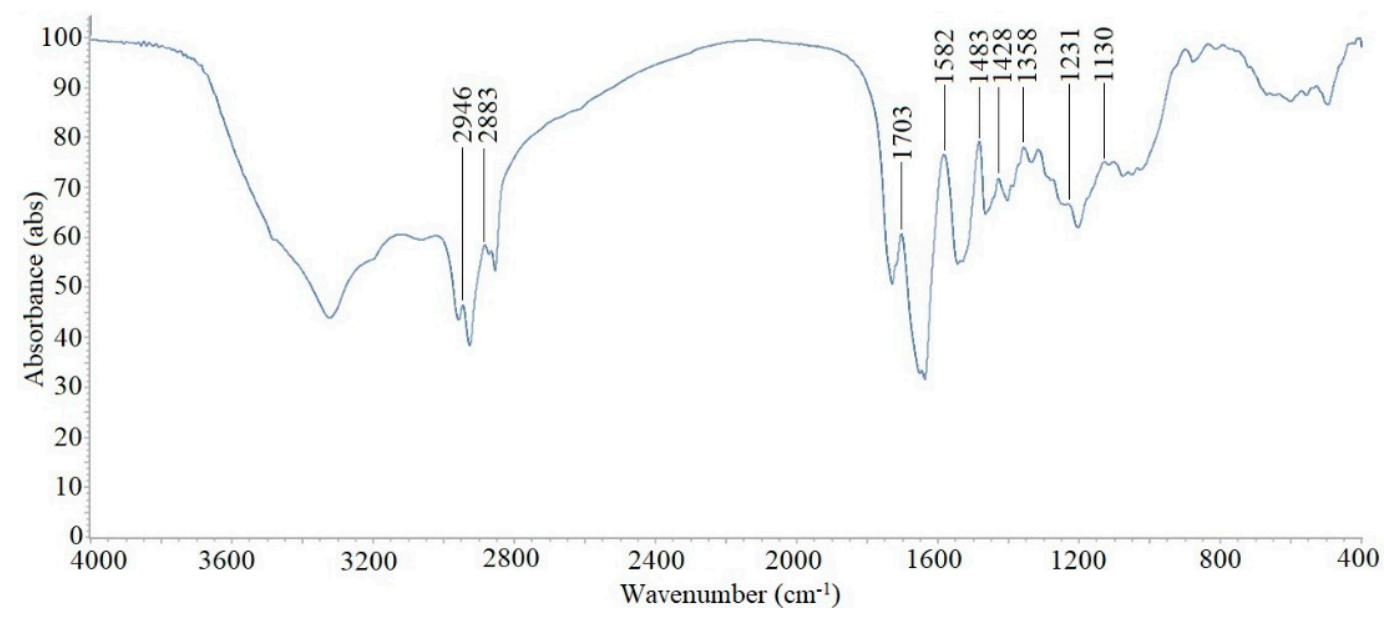

Figure 5. Fourier transform infrared spectroscopy (FTIR) spectrum of the biosurfactant produced by B. licheniformis Ali5.

\subsection{MALDI TOF-MS of Produced Biosurfactant}

Matrix-assisted laser desorption/ionization Time-of-flight mass spectrometry (MALDI-TOF) of the purified biosurfactant (acid precipitation/methanol extract) of B. licheniformis Ali5 strain is shown in (Figure 6). The positive mode operated MALDI-TOF demonstrated mainly the sodium adducts peaks of the compound. A total of 18 peaks were observed having mass to charge ratio within the range from 1015.400-1095.404. [M + Na ${ }^{+}$ions with mass to charge ratio 1015.400, 1029.420, 1030.419, 1043.424, that correspond to the heptapeptide moiety a characteristic of surfactants linked to C13, C14 and C15 hydroxy fatty acid chains. $[\mathrm{M}+\mathrm{K}]^{+\mathrm{s}}$ with mass to charge ratio of 1087.432 . The results of the analysis of B. licheniformis Ali5 produced biosurfactant indicated that the main fractions contain lipids and peptide moieties, which have similarities to lichenysin-A and their homologs. Previous studies $[23,35,36]$ 
authenticated the biosurfactant from B. licheniformis as cyclic heptalipopeptide, having a small peptide chain (Gln, Leu, Val, Asp, lle) that linked to 3-3-hydroxylated tri, tetra and pentadeconoic acids.

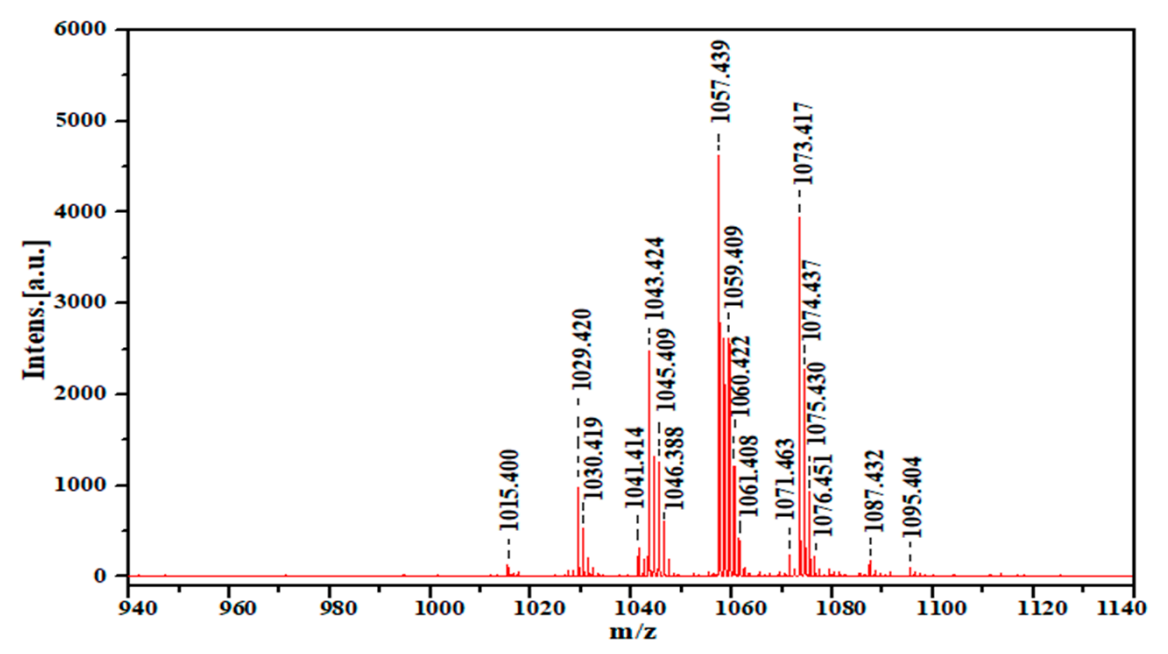

Figure 6. The matrix-assisted laser desorption/ionization time-of-flight (MALDI TOF) spectrum of the biosurfactant produced by B. licheniformis Ali5.

\subsection{Biosurfactant Application in Hydrocarbon Removal from Contaminated Sand}

The degradation and removal of petroleum hydrocarbons bound to the soil is difficult. Surfactants can increase the displacement of hydrocarbons from the soil by making them more water-soluble, lowering their ST and IFT, and by emulsifying hydrocarbons [27]. For the investigation of the hydrocarbon removal from contaminated sand, the $72 \mathrm{~h}$-old cell-free supernatant of M7 glucose-based media and solution of crude biosurfactant was used while the synthetic surfactants Triton X-100, SDS, Tween 80 and Tween 20 at their CMC levels and water as control were used to perform the potential hydrocarbon removal from the sand. Biosurfactant (cell-free supernatant) recovered 79\% (3.9 g) of used motor oil from sand and crude BS solution 70\% (3.5 g), while Triton X-100 63\% (3.15 g), Tween 80 recovered $72 \%$ ( $3.6 \mathrm{~g}$ ) respectively. Water after $24 \mathrm{~h}$ recovered $36-38 \%$ ( $1.8 \mathrm{~g})$ of motor oil from contaminated sand. The biosurfactant successfully recovered more than 2 fold extra oil from sand in comparision with the control (Figure 7). Cell-fee supernatant (CFS) showed promising abilities of hydrocarbon removal from contaminated sand. Biosurfactants are preferred over synthetic surfactants since synthetic surfactants are toxic and have low biodegradability and are harmful to the ecosystem [37]. The cell-free supernatant had slightly higher removal ability then crude BS. This indicates that the cell-free supernatant can be directly used, which can reduce the purification expenses of biosurfactants [38]. Similarly, it was reported that the CFS was as effective as purified biosurfactant; BS from P. aeruginosa removed $80 \%$ hydrocarbons from the sand [39]. Therefore, it may be suggested that the isolated bacterial strain of Bacillus licheniformis Ali5 is a potential candidate for metabolic enhanced oil recovery, bioremediation and in oil industries as it implies a lower cost of biological surfactant production and lower purity specifications. 


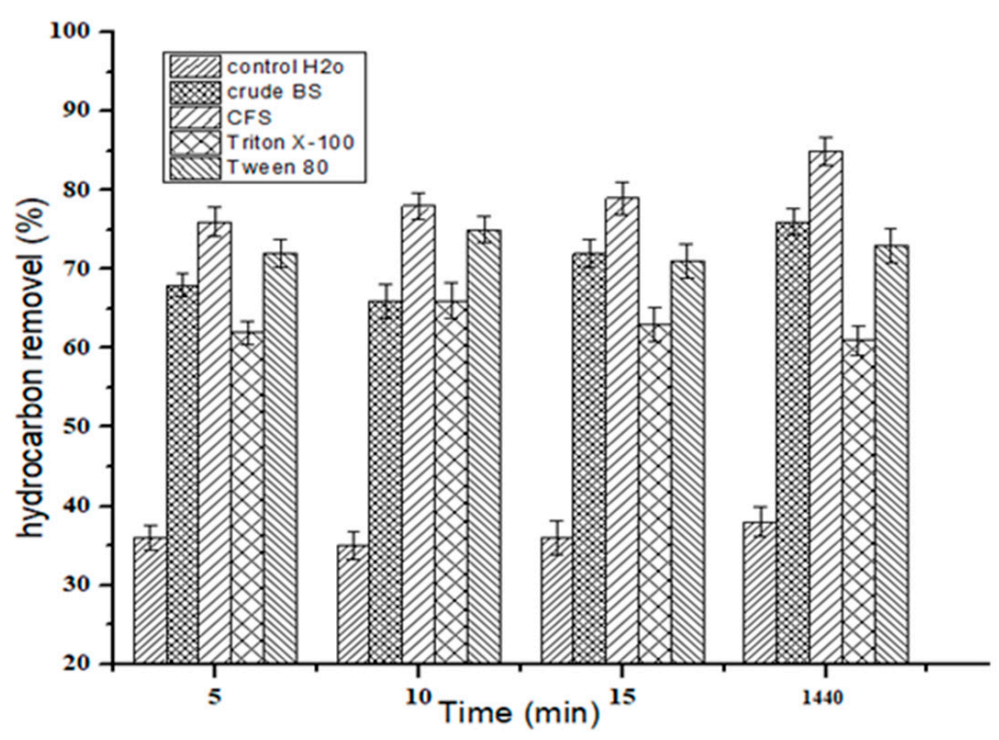

Figure 7. Assessment of crude biosurfactant, CFS = cell-free supernatant, Triton X-100 and Tween 80 on removal of $10 \%(v / w)$ used motor oil from sand. The error bars represent standard deviations from three independent experiments. SD $(n=3)$.

\subsection{Enhanced Oil Recovery Using Sand-Packed Column Test}

To evaluate the potential ability of biosurfactant in ex-situ microbial enhanced oil recovery, biosurfactant was flooded into a sand-packed column. Sand packed in the column is uniform, but it varies in structure and porousness, exhibiting differences in pore volumes from $59-62 \mathrm{~mL}$, original oil in place (OOIP) 45-48 mL, Sorwf 23.6-26.4 mL and Sorbf) from 7.5-8.5 mL in a set of three columns used. Biosurfactant flooding was engaged for additional oil recovery as the water flooding was incapable of recovering the entrapped oil. The water flooding resulted in $7.1 \pm 1.4$ additional oil recovery. Additional oil recovery using biosurfactant (cell-free supernatant) by B. licheniformis Ali5 resulted in (4.5 fold increased) $32.10 \pm 0.4 \%$ as shown in (Table 4 ). It was previously reported by Jha et al. [10] that biosurfactants from $B$. subtilis R1 recovered $33 \pm 1.2 \%$ additional oil using a sand-packed column. Darvishi et al. [30] reported $27 \%$ additional oil recovery with crude biosurfactant and cell-free supernatant using core flood experiment. Wahaibi et al. [26] reported that crude biosurfactant from $B$. subtilis enhanced light oil recovery by $17 \%-26 \%$ and $32 \%$ of additional heavy oil recovery. These results are in agreement with Suthar et al. [40] Gudina et al. [41] and Sun et al. [42] who studied potential ability of biosurfactants using a sand-packed column and reported additional oil recovery below $50 \%$. The biosurfactant produced can desorb entrapped oil from the rocks as it lowers the interfacial tension and makes a stable emulsion, leading to mobilization of crude oil. It brings oil in water phase as the surfactant and it exerts mobility of oil like a polymer. Hence, the mechanism of bioemulsifier is envisaged as surfactant-polymer flooding. These results suggest that microbial metabolites having a combination of surface and interfacial activity along with significant emulsification index (E24) have promising AOR ability. It was also found that the sand-packed column construction was inexpensive, easy and effective. Thus, the sand-packed column performed as a suitable bench-scale method to test the potential ability of biosurfactant in additional oil recovery. 
Table 4. Results obtained in enhanced oil recovery (EOR) sand-packed columns using biosurfactant (CFS) produced by B. licheniformis Ali5.

\begin{tabular}{|c|c|c|c|c|c|c|c|c|}
\hline \multicolumn{9}{|c|}{ Sand-Packed Column Test } \\
\hline \multirow{2}{*}{ Parameters } & \multicolumn{4}{|c|}{ Biosurfactant Flooding } & \multicolumn{4}{|c|}{ Control Flooding } \\
\hline & SP 1 & SP 2 & SP 3 & Mean \pm SD & CT 1 & CT 2 & СТ 3 & Mean \pm SD \\
\hline PV (mL) & 59 & 60 & 62 & $60.3 \pm 1.52$ & 58.0 & 59.0 & 61.0 & $59.3 \pm 1.5$ \\
\hline OOIP (mL) & 46.4 & 45 & 48 & $46.5 \pm 1.50$ & 45.5 & 47.0 & 47.5 & $46.6 \pm 1.0$ \\
\hline $\mathrm{S}_{\mathrm{Oi}}(\%)$ & 78.6 & 75 & 77.4 & $77.0 \pm 1.85$ & 78.4 & 79.6 & 77.8 & $78.6 \pm 0.9$ \\
\hline $\mathrm{S}_{\mathrm{wi}}(\%)$ & 21.4 & 25 & 22.5 & $23.0 \pm 1.86$ & 21.5 & 20.3 & 22.1 & $21.3 \pm 0.9$ \\
\hline $\mathrm{S}_{\text {orwf }}(\mathrm{mL})$ & 23.6 & 24.3 & 26.4 & $24.8 \pm 1.46$ & 22.6 & 20.2 & 23.0 & $21.9 \pm 1.5$ \\
\hline OOIP-S orwf $_{\mathrm{mL}}$ & 22.8 & 20.7 & 21.6 & $21.7 \pm 1.05$ & 22.9 & 26.7 & 24.5 & $24.7 \pm 1.9$ \\
\hline $\mathrm{S}_{\text {or }}(\%)$ & 49.1 & 46 & 45 & $46.7 \pm 2.13$ & 50.3 & 57.0 & 51.5 & $52.9 \pm 3.6$ \\
\hline $\mathrm{S}_{\text {orbf }}(\mathrm{mL})$ & 7.5 & 7.9 & 8.5 & $8.0 \pm 0.51$ & 2.0 & 1.8 & 1.5 & $1.7 \pm 0.3$ \\
\hline AOR (\%) & 31.7 & 32.5 & 32.1 & $32.10 \pm 0.4$ & 8.7 & 6.7 & 6.1 & $7.1 \pm 1.4$ \\
\hline
\end{tabular}

\section{Materials and Methods}

\subsection{Chemicals/Reagents and Isolation of Biosurfactant-Producing Bacteria}

Soil samples with a history of hydrocarbon waste were collected from different locations of the Haidian district of Beijing, PR China. The samples were collected in sterile polyethylene bags, labeled and taken to the laboratory for further study. At regular time intervals, sample moisture was maintained with $0.85 \%$ saline water and stored at room temperature [43]. Samples were serially diluted up to $10^{-6}$ dilutions and plated into mineral salt agar medium (MSM) $\left(1.8 \mathrm{~g} \mathrm{~K}_{2} \mathrm{HPO}_{4}, 4.0 \mathrm{NH} 4 \mathrm{Cl}, 0.2 \mathrm{~g}\right.$ $\mathrm{MgSO} 4.7 \mathrm{H} 2 \mathrm{O}, 0.1 \mathrm{~g} \mathrm{NaCl}, 0.01 \mathrm{~g}$ FeSO4.7H2O, $15 \mathrm{~g}$ agar in $1 \mathrm{~L}$ of distilled water, 1.0\% (v/v) Xinjiang crude oil was used as sole carbon source), incubated at $37^{\circ} \mathrm{C}$ for 16 hours. Morphologically different colonies were re-streaked into nutrient agar plates to obtain a pure culture. Colonies were then tested for biosurfactant activity by using hemolytic activity, oil displacement test, emulsification activity and direct surface tension measurement (ST), isolated bacterial colonized are stored in a refrigerator at $4{ }^{\circ} \mathrm{C}$ as stock culture. All chemicals and hydrocarbons (hexadecane heptane, tridecane, tetradecane and pristane) were purchased from (Sigma-Aldrich, Co USA). Light crude oil was provided by Xinjiang oilfield, China. Kerosene and diesel were purchased from local markets.

\subsection{Screening Assays for Biosurfactant Producers}

\subsubsection{Oil-Spreading Method}

For the oil displacement test, a $90 \times 10 \mathrm{~mm}$ petri dish was filled with $50 \mathrm{~mL}$ distilled water. Crude oil $(10 \mu \mathrm{L})$ was added to form a thin layer on the surface and $10 \mu \mathrm{L}$ of cell-free supernatant was applied on the oil surface. Uninoculated media and $10 \mu \mathrm{L}$ (SDS 10\%) were used as negative and positive control. The displaced diameter was measured, as described by Alvarez et al. [44].

\subsubsection{Drop-Collapsing Test}

The drop-collapse test is a qualitative method to access biosurfactant production. Crude oil $(2 \mu \mathrm{L})$ was dropped into each well of a 96-well micro plate and left overnight to reach equilibrium. Cell-free supernatant $(5 \mu \mathrm{L})$ was dropped into the oil coated wells. Drop size with the magnifying glass was observed. The collapsed drop was recorded as positive for biosurfactant production and the beaded drop was an indicator that the sample does not produce biosurfactant as described by San et al. [45]. 


\subsubsection{Emulsification Index $\left(\mathrm{E}_{24}\right)$ Measurement}

Emulsification activity $\left(\mathrm{E}_{24}\right)$ was measured as described by Chandankere et al. [18]. Different hydrocarbons and $72 \mathrm{~h}$-old supernatant $(5 \mathrm{~mL}$ each) were mixed in glass tubes and vortexed thoroughly for 2 minutes at high speed and maintained at room temperature for $24 \mathrm{~h}$ at static conditions. $\mathrm{E}_{24}$ was performed using hydrocarbons kerosene, hexadecane, tridecane, tetradecane, diesel, crude oil, pristine and heptane. Sodium Dodecyl Sulfate $\left(0.1 \mathrm{~g} \cdot \mathrm{L}^{-1}\right)$, Triton $\mathrm{X}(0.1 \% \mathrm{v} / \mathrm{v})$ was used as control. The $\mathrm{E}_{24}$ was calculated by measuring the stable emulsion layer after $24 \mathrm{~h}$ at room temperature as follows:

Emulsification index $\mathrm{E}_{24}=$ (emulsified layer's height/total height of the liquid $) \times 100$

\subsection{Identification of Selected Bacterial Isolate}

For molecular identification, the isolated bacterial strain was sent to Beijing Liuhe Huada Gene Technology Co., Ltd. (Beijing, China) for sequencing using universal (16S rRNA) primers. The resulting sequence was compared with the sequence in the GeneBank database (NCBI) (https: //blast.ncbi.nlm.nih.gov/Blast.cgi) and the phylogenetic tree was constructed through neighbor-joining methods using MEGA version 6.0 [46].

\subsection{Media Optimization}

The inoculum was prepared in LB medium for biosurfactant production studies, after $14 \mathrm{~h}$ incubation when the fermentation reached an optical density (OD660) of $0.8-0.9,2 \%$ of inoculum was transferred to $250 \mathrm{~mL}$ flasks containing $50 \mathrm{~mL}$ of minimal media, and flasks were incubated in a shaker incubator $\left(250 \mathrm{rpm}\right.$ at $\left.37^{\circ} \mathrm{C}\right)$. Samples were analyzed after $24 \mathrm{~h}$ for growth OD 600, pH, viscosity, ST and IFT. After $72 \mathrm{~h}$, the previously-reported 7 different minimal media were analyzed for BS production, according to method of Al-Sulaimani et al. [3]. The composition of the different previously-reported media is tabulated in Table 5 .

Table 5. The composition of different previously reported minimal media.

\begin{tabular}{|c|c|c|c|c|c|c|c|}
\hline Reference & [47] & [48] & [49] & [50] & [51] & [52] & [53] \\
\hline Composition $\mathrm{g} / \mathrm{L}$ & Media 1 & Media 2 & Media 3 & Media 4 & Media 5 & Media 6 & Media 7 \\
\hline Glucose & 34.0 & 11.0 & 20.0 & 20.0 & 10.0 & 20.0 & - \\
\hline Sucrose & - & - & - & - & - & - & 20.0 \\
\hline $\mathrm{KH}_{2} \mathrm{PO}_{4}$ & 6.0 & - & 1.0 & - & - & 4.8 & 0.14 \\
\hline $\mathrm{K}_{2} \mathrm{HPO}_{4}$ & - & - & - & - & 2.7 & - & 2.2 \\
\hline $\mathrm{Na}_{2} \mathrm{HPO}_{4}$ & 1.0 & - & - & - & - & 7.12 & - \\
\hline $\mathrm{NH}_{4} \mathrm{NO}_{3}$ & 1.0 & - & - & - & - & 4.0 & 3.3 \\
\hline $\mathrm{NaNO}_{3}$ & - & 4.4 & - & 2.8 & - & - & - \\
\hline $\mathrm{MgSO}_{4} \cdot 7 \mathrm{H}_{2} \mathrm{O}$ & 0.1 & 0.8 & 0.5 & 0.20 & 0.25 & 0.2 & 0.6 \\
\hline $\mathrm{FeSO}_{4} \cdot 7 \mathrm{H}_{2} \mathrm{O}$ & 0.0016 & - & - & - & - & 0.0011 & 0.1 \\
\hline $\mathrm{MnSO}_{4} \cdot 4 \mathrm{H}_{2} \mathrm{O}$ & 0.0012 & - & 0.005 & - & - & 0.0006 & - \\
\hline $\mathrm{CaCl}_{2}$ & 0.0012 & - & - & - & - & 0.0007 & 0.01 \\
\hline EDTA & 0.0007 & - & - & 0.2 & - & 0.0014 & - \\
\hline $\mathrm{KCl}$ & - & 0.4 & - & - & - & - & - \\
\hline H3PO4 (85.4\%) & - & $1.0 \mathrm{~mL} / \mathrm{L}$ & - & $0.5 \mathrm{~mL} / \mathrm{L}$ & - & - & - \\
\hline $\mathrm{C}_{5} \mathrm{H}_{8} \mathrm{NO}_{4} \mathrm{Na}$ & - & - & 5.0 & - & - & - & - \\
\hline $\mathrm{CuSO}_{4}$ & - & - & 0.2 & - & - & - & - \\
\hline$\left(\mathrm{NH}_{4}\right)_{2} \mathrm{SO}_{4}$ & - & - & - & - & 1.0 & - & - \\
\hline Yeast extract & - & - & 1.0 & - & 1.0 & - & - \\
\hline $\mathrm{NaCl}$ & - & - & - & - & 5.0 & - & 0.01 \\
\hline Trace elements & - & $10.0 \mathrm{~mL} / \mathrm{L}$ & - & $1.0 \mathrm{~mL} / \mathrm{L}$ & - & - & $0.5 \mathrm{~mL} / \mathrm{L}$ \\
\hline
\end{tabular}

\section{Carbon Source Optimization}

Two selected media were further analyzed for the effect of carbon source on (growth OD600, $\mathrm{pH}$, viscosity, surface tension, interfacial tension, Emulsification index $\left(\mathrm{E}_{24}\right)$, and yield $\left(\mathrm{g} \cdot \mathrm{L}^{-1}\right)$. Carbon sources (glucose, sucrose and starch soluble) were filtered separately before adding to the autoclaved 
media, $2 \%$ seed culture was added to $100 \mathrm{~mL}$ minimal media in $500 \mathrm{~mL}$ Erlenmeyer flasks, fermented in incubator shaker at $37^{\circ} \mathrm{C}$ and $250 \mathrm{rpm}$. Samples were withdrawn at $24 \mathrm{~h}, 48 \mathrm{~h}$ and $72 \mathrm{~h}$ to analyze the growth, $\mathrm{pH}$, viscosity, ST and IFT, yield and emulsification index (E24). Cell-free supernatant after centrifugation $(1000 \times g)$ for 20 minutes was used for all measurements.

\subsection{Determination of Surface Tension, Interfacial Tension and Alteration in Wettability}

The surface tension of 24, 48 and 72-h-old cell-free supernatant was measured using Dataphysics (DCAT11, BW. Filderstadt, Germany) employing Du-Nouy's ring method. The measurement was repeated thrice and each time the platinum ring was washed with distilled water and alcohol, then flamed until red. The interfacial tension of the cell-free supernatant against $n$-heptane was measured using the spinning drop interfacial tensiometer model (TX500C, CNG USA KINO Industry CO. Ltd.) at $25^{\circ} \mathrm{C}$ and $6000 \mathrm{rpm}$ and each result was average of triplicate. The contact angle was measured for both uninoculated media and cell-free supernatant using the Drop Shape Analysis System OCA20, (Dataphysics, Filderstadt, Germany) on hydrophobic surface cover slips at $25^{\circ} \mathrm{C}$ and 1 atm pressure, according to the method of Al-Sulaimani et al. [3].

\subsection{Biosurfactant Extraction and Partial Purification}

Biosurfactant extraction was based on a combination of acid precipitation and solvent extraction as described by Joshi et al. [54]. Bacterial broth was centrifuged at $12,000 \times g$ for $20 \mathrm{~min}$ at $4{ }^{\circ} \mathrm{C}$, collected cell-free supernatant was filtered through a $(0.22 \mathrm{~mm})$ pore-size filter and subjected to acid precipitation ( $\mathrm{HCl} 6 \mathrm{M}) \cdot \mathrm{pH}$ was adjusted to 2 and left at $4{ }^{\circ} \mathrm{C}$ for $12 \mathrm{~h}$. Then, the overnight broth was centrifuged again $\left(12,000 \times \mathrm{g}\right.$ for $20 \mathrm{~min}$ at $\left.4^{\circ} \mathrm{C}\right)$ and the collected pellet was washed twice with acidified water ( $\mathrm{pH} 2$ ). The collected pellet was dried in a hot air oven at $65^{\circ} \mathrm{C}$ and transferred to a $100 \mathrm{~mL}$ conical flask containing $50 \mathrm{~mL}$ methanol and left overnight with intermittent shaking, organic extracted was filtered thrice with methanol and was evaporated using rotary evaporator, a viscous matter was obtained and it was liquefied and $\mathrm{pH}$ adjusted to 8 , then freeze-dried to obtain a light brown crude biosurfactant.

\subsection{Critical Micelle Concentration (CMC) of Biosurfactant}

Critical micelle concentration is the lowest amount of biosurfactant required to achieve maximum surface tension. Above this concentration, all biosurfactant tends to micelle formation and no further reduction in ST is achieved. For CMC determination, $1 \mathrm{~g}$ of freeze-dried biosurfactant was dissolved in Tris HCL-solution pH8 and a series of dilutions were prepared and surface tension was measured for each dilution, as described by Sharma et al. [55].

\subsection{Effect of Environmental Factors on Production and Stability of Biosurfactant}

In the first set of experiments, M7 media with glucose as carbon source were subjected to different internal and external environmental conditions like $\mathrm{pH}(2-12)$ using 6N-HCL/1 N HCL. Salinity (up to 0-30 g. $\left.\mathrm{L}^{-1}\right)$ of $\mathrm{NaCl}$, temperature $\left(20,25,30,35,37,40,45\right.$ and $\left.50{ }^{\circ} \mathrm{C}\right)$, agitation speed $(100,150,200,250$ and $300 \mathrm{rpm})$ and their effect on surface and interfacial tension $\left(\mathrm{mN} \cdot \mathrm{m}^{-1}\right)$ respectively after $72 \mathrm{~h}$ of incubation were studied. Stability of $72 \mathrm{~h}$ old biosurfactant broth was measured by exposing broth to different temperatures (from $40-110{ }^{\circ} \mathrm{C}$ ) overnight and at autoclave conditions $\left(121^{\circ} \mathrm{C}, 15 \mathrm{Psi}\right.$ for $30 \mathrm{~min})$, different $\mathrm{NaCl}$ concentrations $\left(0-30 \mathrm{~g} \cdot \mathrm{L}^{-1}\right)$ and $\mathrm{pH}(2.0-12.0)$. Surface tension and interfacial tension for $\mathrm{pH}$ and salinity was measured immediately and for various temperatures. ST and IFT were measured when the broth was stable at room temperature, according to the method of Hentati et al. [56].

\subsection{Fourier Transform Infrared Spectroscopy (FT-IR)}

For partial identification of structural groups, FTIR was used. The biosurfactant sample (1mg) was mixed with potassium bromide (KBR), pressed for 30 seconds and translucent pellets were obtained. 
Using a Perkin Elmer grating 100 IR (Norwalk, CT, USA) IR spectra were collected from 400-4000 wavenumbers $\left(\mathrm{cm}^{-1}\right)$.

\subsection{Molecular Mass Determination of the Biosurfactant}

MALDI-TOF mass spectrophotometry was carried out for mass-spectrophotometric analysis of the isolated biosurfactant, operating in the positive mode using UltaFlextreme (Bruker-Daltonics Bremen, Germany) in the $m / z$ range of (50-2000 Da). Matrix preparation involves, mixing $2 \mu \mathrm{L}$ of 2, 5 Dihydroxy benzoic acid (DHB) matrix $20 \mathrm{~mL} / \mathrm{mL}$ in TA 30 (30:70 v/v (acetonitrile) ACN:TFA (triflouroacitic acid) $0.1 \%$ TFA) was premixed with $2 \mu \mathrm{L}$ of the sample solution. One microliter of the sample solution was applied to the ground steel target plate and dried at room temperature. Flex software v3.3 (Bruker Daltonics, Germany) was used for visualization and initial data processing, as reported previously by Elshafie et al. [32].

\subsection{Hydrocarbon (Motor Oil) Removal from Soil}

Biosurfactant application for the removal of used motor oil from soil was tested as described previously by Hentati et al. [56]. Soil (50 g) contaminated with 5 grams $(10 \% v / w)$ of used motor oil was transferred to $500 \mathrm{~mL}$ erlenmeyer flasks and were subjected to the following treatments: addition of $100 \mathrm{~mL} 72 \mathrm{~h}$ old supernatant using M7 media, $100 \mathrm{~mL}$ of Milli-Q water as control, $100 \mathrm{~mL}$ of solution of crude biosurfactant at CMC level $\left(21 \mathrm{mg} \cdot \mathrm{L}^{-1}\right)$ and $100 \mathrm{~mL}$ of chemical surfactants at their CMC levels: Tween $80=0.0016 \mathrm{~g}$, and Triton X-100 $=15.5 \mu \mathrm{L}$ in $100 \mathrm{~mL}$ Milli-Q water respectively. The samples were incubated it at $30^{\circ} \mathrm{C}$ and $150 \mathrm{rpm}$ in a rotary shaker for $24 \mathrm{~h}$. Samples were then centrifuged at $10,000 \times g$ for $20 \mathrm{~min}$ and the resulting supernatant was then extracted twice $(v / v)$ with hexane, after the impact of surfactants the amount of the residue oil in the sand was gravimetrically calculated, the percentage of removed oil was calculated with Equation (1).

$$
\text { Motor oil removed }(\%)=\frac{O i-O r}{O i} \times 100
$$

where $O_{i}$ is initial motor oil used in soil before washing $(\mathrm{g}), O_{r}$ is the amount of oil left in soil after washing $(\mathrm{g})$.

\subsection{Enhanced Oil Recovery at Laboratory Scale}

Sand pack column test for potential application of biosurfactant in EOR was constructed as described by Suthar et al. [40] with some modifications. Sand ( $300 \mathrm{~g})$ of particle size $150 \mu \mathrm{m}$ was filled with small amounts to ensure uniform packing in the glass column of inner diameter $45 \times 50 \times 175$ $\mathrm{mm}$. The column was obtained from (Bao Ru YI Biotechnology Co., Ltd. Beijing, China). Two sieves of $1 \mathrm{~mm}$ pore size and $100 \mu \mathrm{m}$ were placed in the upper and lower end, respectively, and tightly fixed at both ends with rubber caps with $1.2 \mathrm{~mm}$ holes for syringe insertion. Tight rubber rings were fixed around the caps for leakage prevention.

(i) Column saturation with brine: To ensure the removal of gases, nitrogen gas for 5 min was passed from the column and a vacuum was held for $5 \mathrm{~min}$. Brine was then flooded at $7 \mathrm{~kg} \cdot \mathrm{cm}^{-2}$ air pressure, pore volume was calculated as the brine volume required for $100 \%$ saturation of the column. Three pore volume (PV) of brine was required for the column saturation.

(ii) Oil saturation of column: Light crude oil (Xinjiang crude oil, China) density $850 \mathrm{~kg} / \mathrm{m}^{3}$ was passed through the sand pack column under pressure, as did earlier with brine until remaining brine saturation is reached. As oil passed in the column it displaced brine which was collected at the bottom end, Soi or initial saturation of oil was calculated by measuring the brine displaced by oil, also called OOIP (original oil in place).

(iii) Column flooding with brine: The column was flooded with brine again and the displaced oil was collected until there was no oil discharge from effluent. The PV of brine flooding was calculated 
to be about 6 to 9 , termed as (Sor). The amount of oil retained was volumetrically determined by measuring the oil displaced. The residue oil saturation (Sor) was measured by assessing the displaced oil volume.

(iv) Biosurfactant flooding: Sand-packed columns were flooded with biosurfactant as described earlier for brine and oil, with 0.6 pore volumes of biosurfactant (CFS), flow rate was set to 3 $\mathrm{mL} / \mathrm{min}$. The biosurficant was passed through the columns, and the columns were incubated for $24 \mathrm{~h}$ following brine flooding. Column discharges were collected and the oil recovered using CFS flooding was measured. The oil recovery percentage was calculated using following formula,

$$
\begin{aligned}
& \text { PV }(\mathrm{mL})=\text { brine volume required for column saturation } \\
& \text { OOIP }(\mathrm{mL})=\text { brine volume displaced by oil saturation }
\end{aligned}
$$

Sorwf $(\mathrm{mL})=$ residual crude oil saturation after water flooding

Sorbf $(\%)=$ oil collected over residual oil saturation after biosurfactant flooding

$$
\text { Swi }(\%)=\frac{x}{p v} \times 100(x=\text { pore volume }- \text { brine collected after oil injection })
$$

$$
\begin{gathered}
\text { Soi }(\%)=\frac{\text { OOIP }}{\mathrm{PV}} \times 100 \\
\text { Sor }(\%)=\frac{\mathrm{Xi}_{\mathrm{i}}}{\text { ooip }} \times 100(\mathrm{Xi}=\text { OOIP }- \text { volume of oil collected after water flooding }
\end{gathered}
$$

$$
\text { AOR over Sorwf }(\%)=\frac{\text { Sorbf }}{\text { OOIP }- \text { Sorwf }} \times 100
$$

\subsection{Statistical Analysis}

All experiments were performed in triplicates, data are expressed as the mean \pm Standard deviation (STDEV.S). A standard statistical software Origin version 8.0 (OriginLab, Massachusetts, USA) was used for all statistical analysis and graphs.

\section{Conclusions}

The potent bacteria B. licheniformis Ali5 was isolated from soil. The isolated bacterial strain displayed the capability for biosurfactant production within $24 \mathrm{~h}$ in carbohydrate-based minimal media. The obtained biosurfactant was characterized as lipopeptide (lichenysin-A) and showed excellent surface and interfacial tension activity, and changed the wettability towards being more water-wet. It was found to be highly stable at extreme environmental conditions. The study also presents a comprehensive explanation about the construction and procedure of the sand-packed column, as a rapid, suitable and less-expensive technique to assess the MEOR potential of biosurfactant. It is found that the bacterial isolate recovered $32.10 \%$ entrapped crude oil from the sand-packed column. Therefore, the isolated bacteria and biosurfactant produced could be highly proficient for environmental applications like microbial enhanced oil recovery and hydrocarbon removal from a polluted environment.

Author Contributions: N.A., F.W. designed the study and N.A. conducted the experiments B.S. C.W., A.U. helped data analysis, M.T.R. and M.N. reviewed manuscript. F.W. and B.X. approved the final version.

Funding: This research was funded by National Key R\&D Program of China, grant number 2017YFB0308900. The APC was funded by Beijing Technology and Business University.

Acknowledgments: The authors are highly grateful to "National Key R\&D Program of China (2017YFB03089)" and "Open Research Program of Beijing Advanced Innovation Center for Soft Matter Science and Engineering" for the support and research grants.

Conflicts of Interest: The authors confirm no conflicts of interest. 


\section{References}

1. He, L.; Lin, F.; Li, X.; Sui, H.; Xu, Z. Interfacial sciences in unconventional petroleum production: From fundamentals to applications. Chem. Soc. Rev. 2015, 44, 5446-5494. [CrossRef] [PubMed]

2. Rudyk, S.; Spirov, P.; Samuel, P.; Joshi, S.J. Vaporization of Crude Oil by Supercritical $\mathrm{CO}_{2}$ at Different Temperatures and Pressures: Example from Gorm Field in the Danish North Sea. Energy Fuels 2017, 31, 6274-6283. [CrossRef]

3. Al-Sulaimani, H.; Al-Wahaibi, Y.; Al-Bahry, S.; Elshafle, A.; Al-Bemani, A.; Joshi, S.; Zargari, S. Optimization and partial characterization of biosurfactants produced by bacillus species and their potential for ex-situ enhanced oil recovery. SPE J. 2011, 16, 672-682. [CrossRef]

4. Al-Wahaibi, Y.; Al-Hadrami, H.; Al-Bahry, S.; Elshafie, A.; Al-Bemani, A.; Joshi, S. Injection of biosurfactant and chemical surfactant following hot water injection to enhance heavy oil recovery. Pet. Sci. 2016, 13, 100-109. [CrossRef]

5. Bryant, R.S.; Donaldson, E.C.; Yen, T.F.; Chilingarian, G.V. Microbial Enhanced Oil Recovery. Dev. Pet. Sci. 1989, 17, 423-450. [CrossRef]

6. Mulligan, C.N. Recent advances in the environmental applications of biosurfactants. Curr. Opin. Colloid Interface Sci. 2009, 14, 372-378. [CrossRef]

7. Santos, D.K.F.; Meira, H.M.; Rufino, R.D.; Luna, J.M.; Sarubbo, L.A. Biosurfactant production from Candida lipolytica in bioreactor and evaluation of its toxicity for application as a bioremediation agent. Process Biochem. 2017, 54, 20-27. [CrossRef]

8. Luna, J.M.; Filho, A.S.S.; Rufino, R.D.; Sarubbo, L.A. Production of biosurfactant from Candida bombicola URM 3718 for environmental applications. Chem. Eng. Trans. 2016, 49, 583-588. [CrossRef]

9. Zhou, W.; Wang, X.; Chen, C.; Zhu, L. Enhanced soil washing of phenanthrene by a plant-derived natural biosurfactant, Sapindus saponin. Colloids Surf. A Physicochem. Eng. Asp. 2013, 425, 122-128. [CrossRef]

10. Jha, S.S.; Joshi, S.J.; Geetha, S.J. Lipopeptide production by Bacillus subtilis R1 and its possible applications. Braz. J. Microbiol. 2016, 47, 955-964. [CrossRef]

11. Simpson, D.R.; Natraj, N.R.; McInerney, M.J.; Duncan, K.E. Biosurfactant-producing Bacillus are present in produced brines from Oklahoma oil reservoirs with a wide range of salinities. Appl. Microbiol. Biotechnol. 2011, 91, 1083-1093. [CrossRef] [PubMed]

12. Nitschke, M.; Pastore, G.M. Production and properties of a surfactant obtained from Bacillus subtilis grown on cassava wastewater. Bioresour. Technol. 2006, 97, 336-341. [CrossRef] [PubMed]

13. Chen, W.C.; Juang, R.S.; Wei, Y.H. Applications of a lipopeptide biosurfactant, surfactin, produced by microorganisms. Biochem. Eng. J. 2015, 103, 158-169. [CrossRef]

14. Verma, N. Biosurfactant Production and Biodesulphurization: Integrated Approach for Fuel Processing. Adv. Biotechnol. Microbiol. 2017, 4, 9-13. [CrossRef]

15. De Almeida, D.G.; Soares Da Silva, R.D.C.F.; Luna, J.M.; Rufino, R.D.; Santos, V.A.; Banat, I.M.; Sarubbo, L.A. Biosurfactants: Promising molecules for petroleum biotechnology advances. Front. Microbiol. 2016, 7, 1718. [CrossRef] [PubMed]

16. Pacwa-Płociniczak, M.; Płaza, G.A.; Piotrowska-Seget, Z.; Cameotra, S.S. Environmental applications of biosurfactants: Recent advances. Int. J. Mol. Sci. 2011, 12, 633-654. [CrossRef] [PubMed]

17. Adelowo, O.O.; Alagbe, S.O.; Ayandele, A.A. Time-dependent stability of used engine oil degradation by cultures of Pseudomonas fragi and Achromobacter aerogenes. Afr. J. Biotechnol. 2006, 5, 2476-2479.

18. Chandankere, R.; Yao, J.; Cai, M.; Masakorala, K.; Jain, A.K.; Choi, M.M.F. Properties and characterization of biosurfactant in crude oil biodegradation by bacterium Bacillus methylotrophicus USTBa. Fuel 2014, 122, 140-148. [CrossRef]

19. Urum, K.; Grigson, S.; Pekdemir, T.; McMenamy, S. A comparison of the efficiency of different surfactants for removal of crude oil from contaminated soils. Chemosphere 2006, 62, 1403-1410. [CrossRef]

20. Lai, C.C.; Huang, Y.C.; Wei, Y.H.; Chang, J.S. Biosurfactant-enhanced removal of total petroleum hydrocarbons from contaminated soil. J. Hazard. Mater. 2009, 167, 609-614. [CrossRef]

21. Osunde, J.E.; Balogun, S.A. Micro-organisms in enhanced oil recovery. Ife J. Sci. 2013, 15, 617-630.

22. Varjani, S.J.; Pollution, G.; Board, C.; Bateja, S.; Gas, N.; Limited, C.; Upasani, V.N. Screening and identification of biosurfactant (bioemulsifier) producing bacteria from crude oil contaminated sites of Gujarat, India. Int. J. Innov. Res. Sci. Eng. Technol. 2014, 3297, 9205-9213. 
23. Joshi, S.J.; Al-Wahaibi, Y.M.; Al-Bahry, S.N.; Elshafie, A.E.; Al-Bemani, A.S.; Al-Bahri, A.; Al-Mandhari, M.S. Production, characterization, and application of bacillus licheniformis W16 biosurfactant in enhancing oil recovery. Front. Microbiol. 2016, 7, 1853. [CrossRef] [PubMed]

24. Purwasena, I.A.; Astuti, D.I.; Syukron, M.; Amaniyah, M.; Sugai, Y. Stability test of biosurfactant produced by Bacillus licheniformis DS1 using experimental design and its application for MEOR. J. Pet. Sci. Eng. 2019, 183. [CrossRef]

25. De Faria, A.F.; Teodoro-Martinez, D.S.; De Oliveira Barbosa, G.N.; Gontijo Vaz, B.; Serrano Silva, Í.; Garcia, J.S.; Tótola, M.R.; Eberlin, M.N.; Grossman, M.; Alves, O.L.; et al. Production and structural characterization of surfactin (C 14/Leu7) produced by Bacillus subtilis isolate LSFM-05 grown on raw glycerol from the biodiesel industry. Process Biochem. 2011, 46, 1951-1957. [CrossRef]

26. Al-Wahaibi, Y.; Joshi, S.; Al-Bahry, S.; Elshafie, A.; Al-Bemani, A.; Shibulal, B. Biosurfactant production by Bacillus subtilis B30 and its application in enhancing oil recovery. Colloids Surf. B Biointerfaces 2014, 114, 324-333. [CrossRef]

27. Banat, I.M.; Satpute, S.K.; Cameotra, S.S.; Patil, R.; Nyayanit, N.V. Cost effective technologies and renewable substrates for biosurfactants' production. Front. Microbiol. 2014, 5, 697. [CrossRef]

28. Joshi, S.J.; Geetha, S.J.; Desai, A.J. Characterization and Application of Biosurfactant Produced by Bacillus licheniformis R2. Appl. Biochem. Biotechnol. 2015, 177, 346-361. [CrossRef]

29. Dubey, K.V.; Charde, P.N.; Meshram, S.U.; Shendre, L.P.; Dubey, V.S.; Juwarkar, A.A. Surface-active potential of biosurfactants produced in curd whey by Pseudomonas aeruginosa strain-PP2 and Kocuria turfanesis strain-J at extreme environmental conditions. Bioresour. Technol. 2012, 126, 368-374. [CrossRef]

30. Darvishi, P.; Ayatollahi, S.; Mowla, D.; Niazi, A. Biosurfactant production under extreme environmental conditions by an efficient microbial consortium, ERCPPI-2. Colloids Surf. B Biointerfaces 2011, 84, 292-300. [CrossRef]

31. Bognolo, G. Biosurfactants as emulsifying agents for hydrocarbons. Colloids Surf. A Physicochem. Eng. Asp. 1999, 152, 41-52. [CrossRef]

32. Elshafie, A.E.; Joshi, S.J.; Al-Wahaibi, Y.M.; Al-Bemani, A.S.; Al-Bahry, S.N.; Al-Maqbali, D.; Banat, I.M. Sophorolipids production by Candida bombicola ATCC 22214 and its potential application in microbial enhanced oil recovery. Front. Microbiol. 2015, 6, 1324. [CrossRef] [PubMed]

33. Sajna, K.V.; Sukumaran, R.K.; Gottumukkala, L.D.; Pandey, A. Crude oil biodegradation aided by biosurfactants from Pseudozyma sp. NII 08165 or its culture broth. Bioresour. Technol. 2015, 191, 133-139. [CrossRef] [PubMed]

34. Pereira, J.F.B.; Gudiña, E.J.; Costa, R.; Vitorino, R.; Teixeira, J.A.; Coutinho, J.A.P.; Rodrigues, L.R. Optimization and characterization of biosurfactant production by Bacillus subtilis isolates towards microbial enhanced oil recovery applications. Fuel 2013, 111, 259-268. [CrossRef]

35. Mikkola, R.; Kolari, M.; Andersson, M.A.; Helin, J.; Salkinoja-Salonen, M.S. Toxic lactonic lipopeptide from food poisoning isolates of Bacillus licheniformis. Eur. J. Biochem. 2000, 267, 4068-4074. [CrossRef]

36. Vater, J.; Kablitz, B.; Wilde, C.; Franke, P.; Mehta, N.; Cameotra, S.S. Matrix-assisted laser desorption ionization-time of flight mass spectrometry of lipopeptide biosurfactants in whole cells and culture filtrates of Bacillus subtilis C-1 isolated from petroleum sludge. Appl. Environ. Microbiol. 2002, 68, 6210-6219. [CrossRef]

37. De França,Í.W.L.; Lima, A.P.; Lemos, J.A.M.; Lemos, C.G.F.; Melo, V.M.M.; De Sant'ana, H.B.; Gonçalves, L.R.B. Production of a biosurfactant by Bacillus subtilis ICA56 aiming bioremediation of impacted soils. Catal. Today 2015, 255, 10-15. [CrossRef]

38. Silva, S.N.R.L.; Farias, C.B.B.; Rufino, R.D.; Luna, J.M.; Sarubbo, L.A. Glycerol as substrate for the production of biosurfactant by Pseudomonas aeruginosa UCP0992. Colloids Surf. B Biointerfaces 2010, 79, 174-183. [CrossRef]

39. Li, Z.; Zhang, Y.; Lin, J.; Wang, W.; Li, S. High-Yield Di-Rhamnolipid Production by Pseudomonas aeruginosa YM4 and its Potential Application in MEOR. Molecules 2019, 24, 1433. [CrossRef]

40. Suthar, H.; Hingurao, K.; Desai, A.; Nerurkar, A. Evaluation of bioemulsifier mediated Microbial Enhanced Oil Recovery using sand pack column. J. Microbiol. Methods 2008, 75, 225-230. [CrossRef]

41. Gudiña, E.J.; Pereira, J.F.B.; Costa, R.; Coutinho, J.A.P.; Teixeira, J.A.; Rodrigues, L.R. Biosurfactant-producing and oil-degrading Bacillus subtilis strains enhance oil recovery in laboratory sand-pack columns. J. Hazard. Mater. 2013, 261, 106-113. [CrossRef] [PubMed] 
42. Sun, G.; Hu, J.; Wang, Z.; Li, X.; Wang, W. Dynamic investigation of microbial activity in microbial enhanced oil recovery (MEOR). Pet. Sci. Technol. 2018, 36, 1265-1271. [CrossRef]

43. Reddy, C.O. Isolation and characterization of biosurfactant producing bacteria from groundnut oil cake dumping site for the control of foodborne pathogens. Grain Oil Sci. Technol. 2019, 2, 15-20. [CrossRef]

44. Alvarez, V.M.; Jurelevicius, D.; Marques, J.M.; de Souza, P.M.; de Araújo, L.V.; Barros, T.G.; de Souza, R.O.M.A.; Freire, D.M.G.; Seldin, L. Bacillus amyloliquefaciens TSBSO 3.8, a biosurfactant-producing strain with biotechnological potential for microbial enhanced oil recovery. Colloids Surf. B Biointerfaces 2015, 136, 14-21. [CrossRef]

45. San Keskin, N.O.; Han, D.; Devrim Ozkan, A.; Angun, P.; Onarman Umu, O.C.; Tekinay, T. Production and structural characterization of biosurfactant produced by newly isolated staphylococcus xylosus STF1 from petroleum contaminated soil. J. Pet. Sci. Eng. 2015, 133, 689-694. [CrossRef]

46. Datta, P.; Tiwari, P.; Pandey, L.M. Isolation and Characterization of Biosurfactant Producing and Oil Degrading Bacillus Subtilis MG495086 from Formation Water of Assam Oil Reservoir and its Suitability for Enhanced Oil Recovery; Elsevier: Amsterdam, The Netherlands, 2018; Volume 270, ISBN 9136125822. [CrossRef]

47. Joshi, S.; Bharucha, C.; Desai, A.J. Production of biosurfactant and antifungal compound by fermented food isolate Bacillus subtilis 20B. Bioresour. Technol. 2008, 99, 4603-4608. [CrossRef]

48. Yadav, S.; Nerurkar, A.; Desai, A.J. Statistical Optimization of Medium Components for the Production of Biosurfactant by Bacillus licheniformis K51. J. Microbiol. Biotechnol. 2007, 17, 313-319.

49. Landy, M.; Warren, G.H.; Rosenmanm, S.B.; Colio, L.G. Bacillomycin: An Antibiotic from Bacillus subtilis Active against Pathogenic Fungi. Proc. Soc. Exp. Biol. Med. 1948, 67, 539-541. [CrossRef]

50. Jenny, K.; Kiippeli, O.; Fiechter, A. Applied Microbiology Biotechnology Biosurfactants from Bacillus licheniformis: Structural analysis and characterization. Appl. Microbiol. Biotechnol. 1991, 36, 5-13. [CrossRef]

51. Youssef, N.; Simpson, D.R.; Duncan, K.E.; McInerney, M.J.; Folmsbee, M.; Fincher, T.; Knapp, R.M. In Situ Biosurfactant Production by Bacillus Strains Injected into a Limestone Petroleum Reservoir. Appl. Environ. Microbiol. 2007, 73, 1239-1247. [CrossRef]

52. Cooper, D.G.; Macdonald, C.R.; Duff, S.J.B.; Kosaric, N. Enhanced production of surfactin from Bacillus subtilis by continuous product removal and metal cation additions. Appl. Environ. Microbiol. 1981, 42, 408-412. [PubMed]

53. Mukherjee, S.; Das, P.; Sen, R. Rapid quantification of a microbial surfactant by a simple turbidometric method. J. Microbiol. Methods 2009, 76, 38-42. [CrossRef] [PubMed]

54. Joshi, S.J.; Desai, A.J. Bench-Scale Production of Biosurfactants and their Potential in Ex-Situ MEOR Application. Soil Sediment Contam. 2013, 22, 701-715. [CrossRef]

55. Sharma, D.; Saharan, B.S.; Chauhan, N.; Procha, S.; Lal, S. Isolation and functional characterization of novel biosurfactant produced by Enterococcus faecium. Springerplus 2015, 4, 4. [CrossRef]

56. Hentati, D.; Chebbi, A.; Hadrich, F.; Frikha, I.; Rabanal, F.; Sayadi, S.; Manresa, A.; Chamkha, M. Production, characterization and biotechnological potential of lipopeptide biosurfactants from a novel marine Bacillus stratosphericus strain FLU5. Ecotoxicol. Environ. Saf. 2019, 167, 441-449. [CrossRef]

Sample Availability: Samples of the compounds Lichenysin are not available from the authors.

(C) 2019 by the authors. Licensee MDPI, Basel, Switzerland. This article is an open access article distributed under the terms and conditions of the Creative Commons Attribution (CC BY) license (http://creativecommons.org/licenses/by/4.0/). 